\title{
A MEDVES-VIDÉK DÉLI PEREMÉNEK HOMOKKŐKÉPZŐDMÉNYEI
}

Sandstone formations on the southern rim of the Medves Area, North Hungary

\section{PINTÉR ZOLTÁN}

ELTE TTK Földrajz- és Földtudományi Intézet, ny. főiskolai adjunktus

\begin{abstract}
The Medves Area, which is part of the Novohrad-Nógrád Geopark, is a small landscape unit in North Hungary, having several interesting geological landforms and from some aspects a special geomorphology. Its southern rim is almost unknown both from point of view of the geosciences and the tourism. Wandering and field work is not easy in this area due to the deep zigzag gorges and lush vegetation; however, it is very awakening to discover the landscape. The area is consisting of mainly sandstones and it is possible to study the very unique landforms, among others outcropped mushroom rocks and several microforms, moreover gives opportunity to recognize their development. The personal experience can provide much more benefit and pleasure e. g. for a geography teacher than to study a series of figures in a textbook. On the other hand, it also induces for further research.
\end{abstract}

Keywords: Medves Area, Novohrad-Nógrád Geopark, field work, sandstone, denudation, microforms, concretions

\section{BEVEZETÉS}

A Medves-vidék déli peremterülete mind turisztikai, mind természetföldrajzi feltártság szempontjából egy teljesen ismeretlen országrész. Abban az esetben, ha valaki vállalja az úttalan utakon való túrázást a meredek domboldalakon, az átkelést a sürü növényzettel benőtt mély vízmosások zegzugos rendszerében, akkor nagyon tanulságos földrajzi felfedező úton járhat. Mi adja a felfedezés örömét? A területet felépítő homokkövön kialakult kis- és nagyformák változatossága. A homokkő lepusztulásformáinak valóságos tárháza ez a légvonalban alig $8 \mathrm{~km}$ hosszú sáv. Itt a természetben nyerhetünk teljes képet a gombasziklák kialakulásáról, azok képződési fokozatai alapján, és ez a közvetlen, valóságbeli megtapasztalás többet érhet bármely tankönyvi ábrasorozatnál. Míg a képek, ábrák érdeklődést kelthetnek fel, addig az emberközeli távolságban lévő, közvetlenül tapintható valóság elgondolkodtat, az új felmerülő kérdésekre adandó válasz keresése pedig további kutatásra késztet és maradandó élményt nyújt. 


\section{A TERÜLET FEKVÉSE ÉS DOMBORZATÁNAK FEJLŐDÉSE}

A Medves-vidék a Magyarország Nemzeti Atlaszában (Kocsis K. 2018) megjelentetett legújabb természetföldrajzi tájbeosztás alapján az Északi-középhegység MedvesVajdavár-vidék nevü kistájcsoportjának $160 \mathrm{~km}^{2}$ területü kistája, amely nagyjából a Zagyva, a Tarján- és a Bárna-patakok völgyei között terül el (1.ábra). Teljes egészében első geoparkunk, a szlovákiai és magyarországi területeket is magában foglaló NovohradNógrád Geopark része. Északon valójában túlnyúlik az országhatáron, szerves folytatását alkotja a nagyon hasonló felépítésủ és domborzatú, a szlovákiai geomorfológiai tájbeosztás által Cerová vrchovinának (Cseres-hegység) nevezett dombvidék, és sok tekintetben hasonló formakincsü kistáj határolja kelet felé, mégpedig a kistájcsoport másik névadó tagja, a Vajdavár-vidék (4. ábra).

A Medves-vidék domborzata erősen tagolt és meglehetősen változatos (HORvátH G. 1997, 1998, GAÁL L. - HoRvátH G. 2007). Északon bazaltból felépülő takarók, kürtökitöltések teszik látványos és változatos arculatúvá, ott található legmagasabb (638 m) pontja a Medves fennsíkjából kiemelkedő és az országhatár által kettévágott Medves magosa magyarországi részén. Legalacsonyabb délnyugaton, a Zagyva és a Tarján-patak összefolyásánál. Itt délen a Zagyva völgymedencéje által határolt kistáj déli sávjának felszínét főleg a pleisztocénben lezajlott szerkezeti mozgások, a törésekkel-vetődésekkel jellemezhető kiemelkedés, valamint a külső erők, főleg a völgyképződéssel járó folyóvízi erózió formálták és formálják napjainkban is. A völgymedence süllyedése, illetve

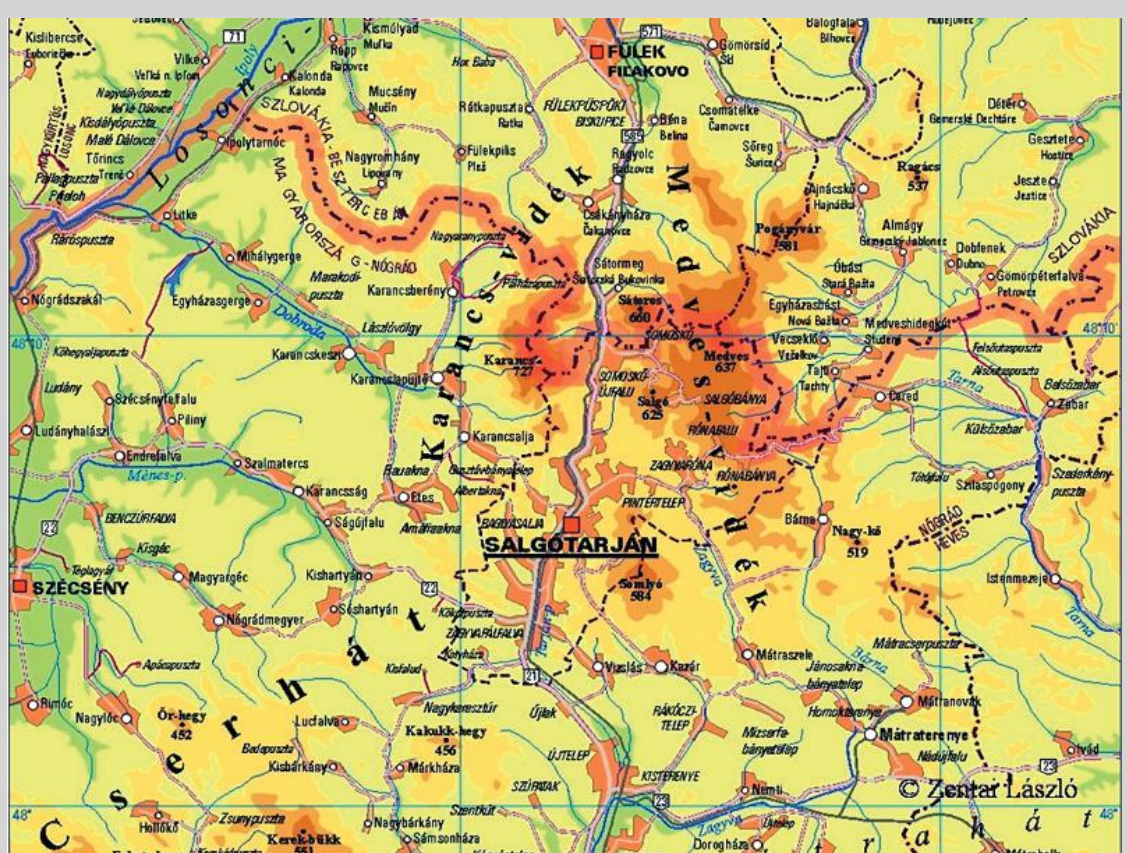


a rögvidék kiemelkedése kis távolságon belül jelentős szintkülönbségeket alakított ki: a Zagyva medencéjének 210 m-ről 190 m-ig lejtő szintjét északról 330-360 m magas csúcsokban tetőző vonulatok övezik (PINTÉr Z. 2001, 2003).

A dombság déli peremének teljes hosszát a különböző magasságba vetett keskenyebb-szélesebb töréslépcsők szintjei határozzák meg. A töréslépcsőket általában meredek vetőfelületek kötik össze. A kiemelt rögökre jellemző a jelentős, általában 30-35'-os északkeleties kibillenés is. Ennek a szerkezeti meghatározottságnak döntő jelentősége van a felszínformák kialakulásában. A rögök kiemelkedése és kibillenése a térség kőzeteinek jellegzetes, mozaikos felszíni előfordulását eredményezte. A déli peremen többnyire a miocén rétegsorozat legalsóbb helyzetü, legidősebb homokköves képződményei vannak kiemelt, míg a fiatalabb képződmények (riolittufa, kőszenes sorozatok, agyag) mögöttes, lezökkent helyzetben, a rögsorozatok északi felén bukkannak elő. Ezt a szerkezetföldtani vázat a lepusztulás átformálta; míg az északabbra fekvő alacsonyabb helyzetű dombvidék javarészt megőrizte a jégkorban kialakult deráziós, mart-koptatott formakincsét, addig a déli magasabb területen a pleisztocén-holocén vonalas eróziós tevékenység eltüntette, átalakította azokat. Ez különösen jellemző a déli sávra, ahol a rövid távolságon belüli nagyobb szintkülönbségek miatt sürü völgyhálózat jött létre (2. ábra), hosszabb-rövidebb, keskenyebb-szélesebb eróziós hátakká, gerincekké szabdalva fel a töréslépcsős sávot (PINTÉR Z. 2001, 2003).

Ezek a völgyek lényegében mind aszóvölgyek, azaz az év túlnyomó részében szárazak, vízfolyás nélküliek, egy-egy esőzési időszakot követően azonban hirtelen nagy tömegü

2. ábra. A Zagyva medencéjéböl Nemti település mentén kiemelkedő Nemti-rögvidék térképvázlata (szerk. Pintér Z.)

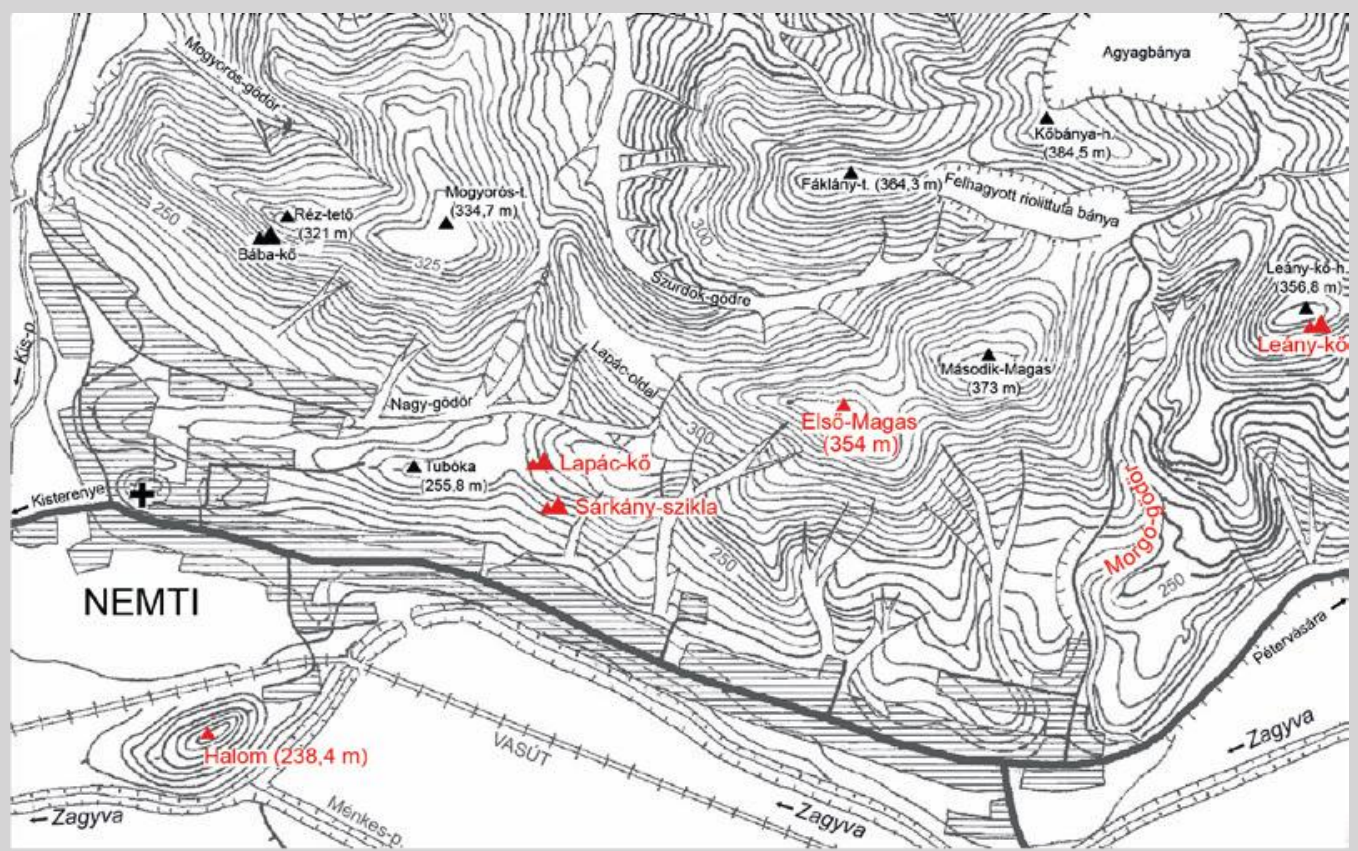


víz zúdul végig rajtuk. Formálódásuk, gyors kimélyülésük főleg a holocén bő csapadékú korszakaiban zajlott le, ez a fejlődés azonban minden bizonnyal hirtelen ért véget, amit a völgyfök és völgyoldalak máig meredeken megmaradt, nem ritkán több méter mély falai tanúsítanak, ennek jellemző példája a 2. ábra térképvázlatán is ábrázolt Morgó-gödör (3. a-b. ábra). A terepet hosszabb időn át többször is bejárva jól érzékelhető, hogy ezeknek az aszóvölgyeknek a fejlődése, hirtelen kimélyülése ma is alapvetően a ritkán előforduló, igen nagy mennyiségü csapadékhulláskor jelentős.

Magának a Zagyva-ároknak a kialakulását is jellegzetes lépcsős vetődések sorozata eredményezte. A folyamatra két példát is megfigyelhetünk. Az egyik Nemti település határában található, ahol a folyóvízi feltöltésű Zagyva-sík 205 m-es szintjéből emelkedik ki - a dombságtól teljesen elkülönülő helyzetben - a homokkőből felépülő 238 m-es Halom magaslata (2. ábra), míg a másik Kisterenye belterületén a medencesík 190 m-es szintjéből kiemelkedő, 217 m-es erodált kúp, amely körbeépítettsége miatt kevésbé feltűnő. Mindkettő egy-egy vetődött, az árok talpának szintje fölé emelkedő rög.

\section{A LEGJELLEGZETESEBB KÖZET: A MESZES HOMOKKŐ}

A homokkő legrövidebb és legkifejezőbb meghatározása szerint „tömörödött és cementálódott (litifikált) homok” (BAlogh K. - Hajdúné Molnár K. 1991. p. 102.).

3. ábra. A Morgó-gödör eróziós szurdokvölgyének rendkivül keskeny (a) és torkolat felé kissé kiszélesedö (b) völgyszakasza (fotó: Karancsi Z.)
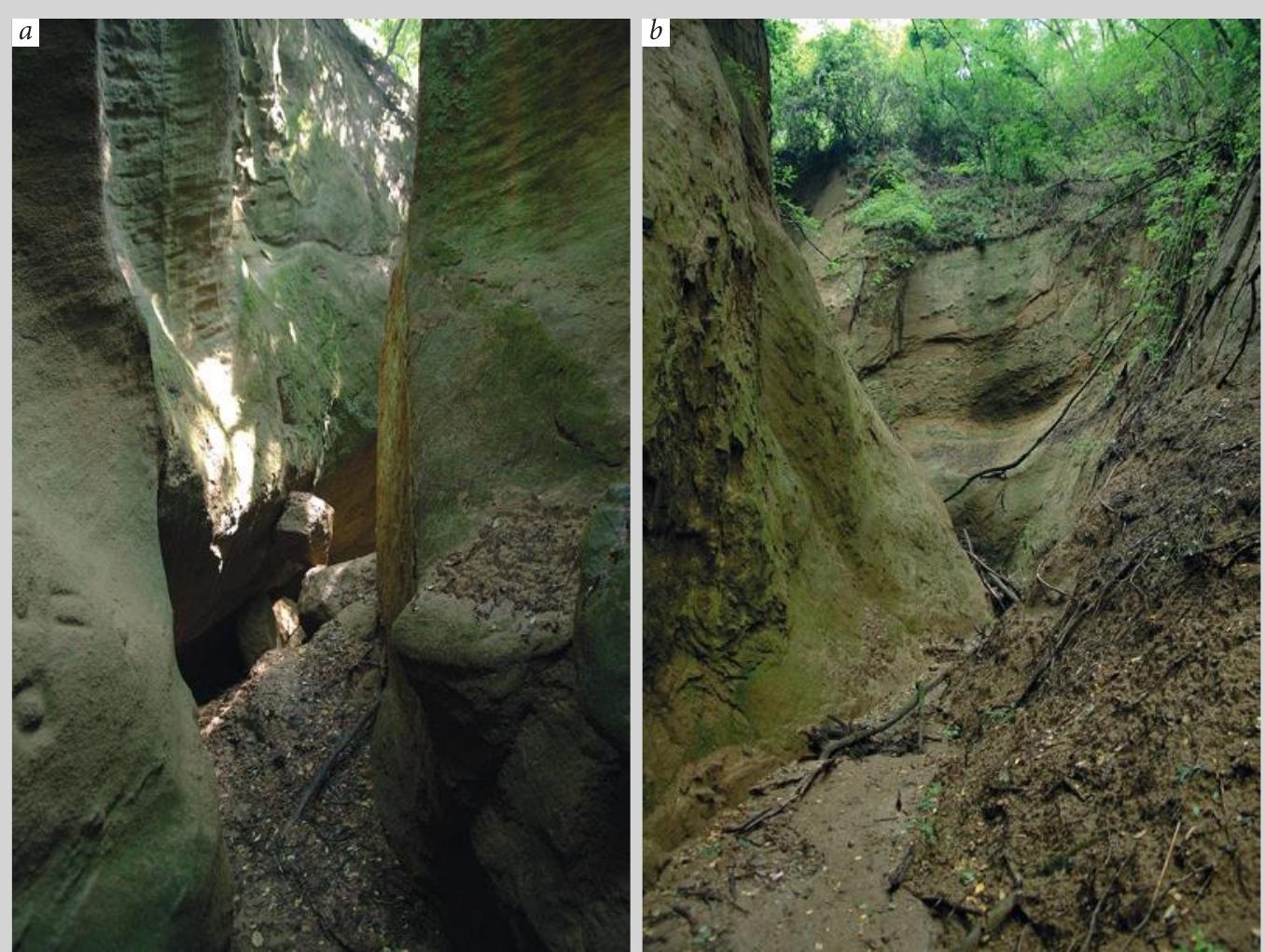
Szemcsenagysága a 0,06-2,00 mm közötti tartományba esik. A homokszemcsék általában felhalmozódási helyüktől távolabbról származnak, tengeri felhalmozódás esetén folyóvízi és szél általi behordódásúak.

Összetételükben három fő alkotóelem vesz részt. Egyrészt maguk a homokszemcsék, amelyekben kiemelkedően magas a koptatásnak, oldódásnak ellenálló kvarc aránya (65\%), emellett a földpátszemcsék 12\%-os aránya mellett jelentős lehet a csillámok mennyisége is, a könnyebben málló biotittal szemben különösen az ellenálló muszkovité. A másik alkotó elemet a földtanos szakma mátrixnak nevezi, ebbe a 0,06 mm-nél kisebb szemcsenagyságú anyag tartozik. Végül a harmadik a homokszemcsék összetapasztásában szerepet játszó cementanyag; gyakoriságuk sorrendjében a legjellemzőbb kötőanyagok a kalcit, kvarc, dolomit, sziderit, anhidrit, muszkovit, kaolinit, klorit, káliföldpát stb. (BAlogh K. - Hajdúné Molnár K. 1991). Ennek alapján beszélhetünk meszes, agyagos, limonitos, hematitos, gipszes stb. homokkövekröl.

A cementáló anyagok közül legelterjedtebb a meszes kötőanyag. A tengerben adottak a karbonátos kötőanyag képződésének a feltételei. A tengervíz jelentős mennyiségü $\mathrm{CaCO}_{3}$-ot képes feloldani, és a jól ismert kloridos, bromidos, szulfidos sók mellett jelentős a $\mathrm{Ca}^{2+}, \mathrm{Mg}^{2+}, \mathrm{HCO}_{3-}$ ionok koncentrációja. A tengervízben szemcsés formában is jelen van a karbonát, amely tengeri élőlények meszes vázanyagából származik. A víz hőmérsékletének emelkedése elősegíti az oldott állapotban lévő mészanyag kicsapódását.

A homok tengeri felhalmozódásának, lerakódásának feltételét a szárazföldről behordott törmelékanyag folyamatos utánpótlása adja. A lerakódás kis lejtésű, sekélyvizű környezetben biztosított, ahol az anyag elteregetését kis és közepes hullámzás, az árapályjelenség és az ezek keltette áramlások végzik. A felhalmozódásnak a 20-30 m-es tengermélység a legmegfelelőbb. A folyamatosan süllyedő és előrenyomuló tengermedencékben nagy területen és akár több $100 \mathrm{~m}$ vastagságban is rakódhat le a homok. Az ily módon felhalmozódott üledék kőzetté válása a betemetődés mélységétől, az üledék és a cementanyag minőségétől függ. A kőzetté válás fokmérője a kőzet kötöttségének a mértéke. A kötöttség a mátrix és a cement minőségétől és főleg mennyiségétől függ.

A kötöttségnek 3 fokozatát különböztetik meg (BALOGH K. - HAJdúnÉ MolnáR K. 1991). a) A laza, kötetlen homok mátrix- és cementmentes. A homok szemcséin ásványi bevonatok képződhetnek, amelyek jellegzetes színt kölcsönöznek az összletnek. Leggyakoribb a rozsdabarna színeket adó limonit.

b) A kötött homokkő szilárdságát főként a mátrix anyaga adja. Ez felelős a homokkő állékonyságáért. A kötött homokkő tömegei meredek falakban állhatnak meg, amelyek alámosáskor hasadozva omlanak le (3a. ábra).

c) A tömör homokkő ellenálló képességét az erős kötést biztosító cementanyag adja. 


\section{AZ URALKODÓ PÉTERVÁSÁRAI HOMOKKŐ FORMÁCIÓ}

A nagyjából az Ipolytarnóc - Ózd - Pétervására települések által meghatározott háromszög alakú terület - amely jórészt felöleli a Medves-vidéket is (4. ábra) - uralkodó homokköves kőzetét a Magyar Rétegtani Bizottság a Pétervásárai Homokkö Formációba sorolja (BÁldi T. 1983, HÁMOR G. 1985, Sztanó O. 1994, Gyalog L. 1996, Prakfalvi P. et al. 2007).

Képződése a miocén kor eggenburgi korszakában történt a középidő Tethysóceánjának utódtengere, a Paratethys folyamatosan mélyülő és előrenyomuló partközeli, sekélytengeri környezetében. (BÁLDI T. [2003] ezt a tengert létezési ideje alapján Eggenburgi-tengernek nevezi.) A nagyjából 23-18 millió évvel ezelőtti időszakaszban felhalmozódott kőzetsorozat összvastagsága 200-600 m közötti. A kőzetsorozat a keletkezési viszonyok változásait követve jelentős rétegzettséget mutat. Szemcsenagysága a finom-, apró- és középszemű kategóriába esik. Átlagos mésztartalma 6-8\%, ami a padokban, konkréciókban elérheti a 15-25\%-ot. Rétegzettségét főleg ezek a padok, konkréciósorok, valamint az esetenkénti kavicszsinórok mutatják. Színe szárazon sárga, szürkésfehér, nedvesen szürke, zöldesszürke (BÁLDI T. 1983, HÁMOR G. 1985).

A Medves-vidék és a Vajdavár-hegység területén a Pétervásári Homokkő Formáció felszínformáinak nagy változatossága tanulmányozható (PInTÉR Z. 2001, 2003, GAÁL L. - Horváth G. 2007, Horváth G. 2007, Horváth G. et al. 2015, Veres Zs. - Varga A. 2020). A homokkő egyik fő jellegzetességét a kőzetté válással egyidőben keletkezett (szingenetikus) konkréciók jelentős mennyisége adja. Konkréciónak - leegyszerüsítve - egyes

4. ábra. A Pétervásári Homokkő Formáció elterjedése (Sztanó O. 1994 nyomán szerk. Karancsi Z.) Jelmagyarázat: a barna pontok felszíni közetkibukkanásokat jelölnek.

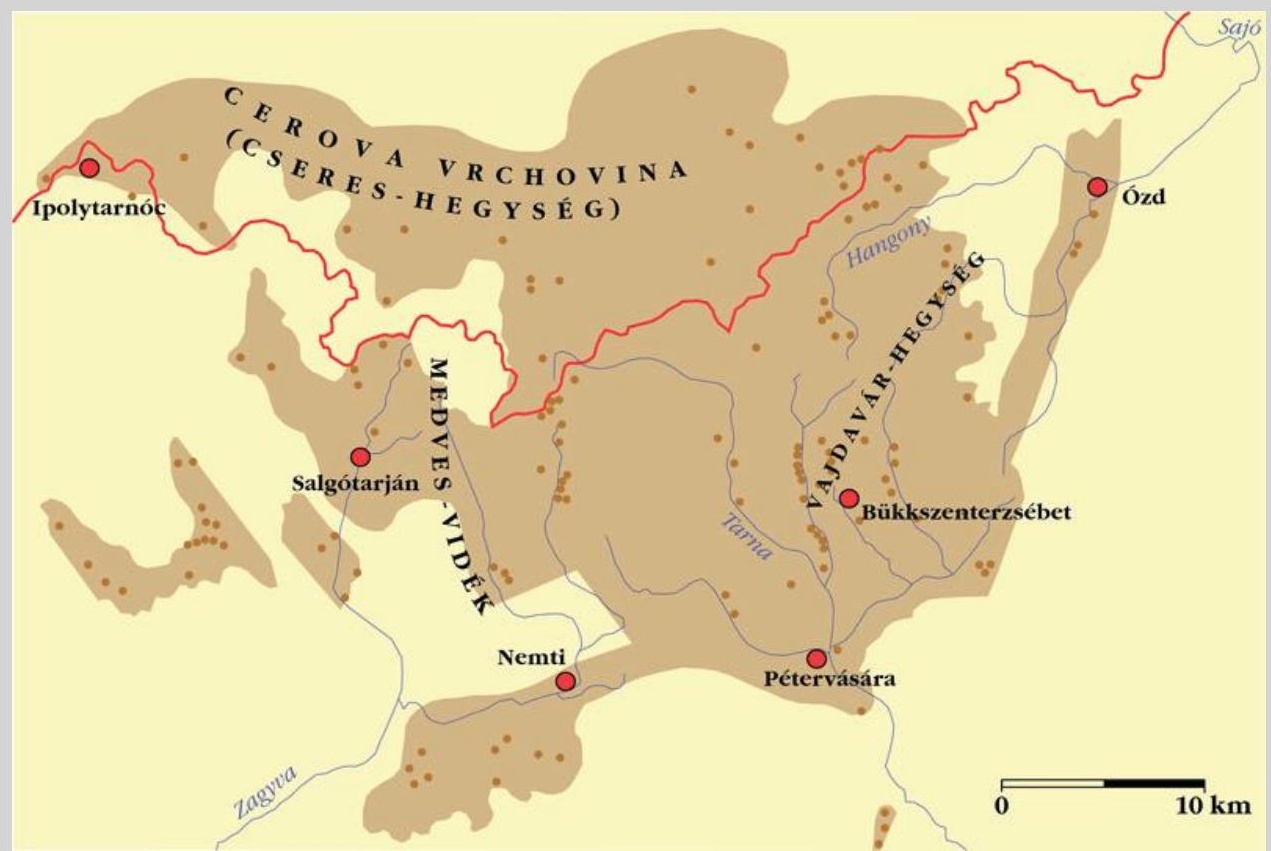


üledékes kőzetek finom eloszlású ásványi anyagainak egy kiválási központ körüli összetömörülését nevezzük. A konkréció alakját a külső körülmények befolyásolják. A térségben a homokkövekben előforduló konkréciókat gyakran gömbölyded alakjuk alapján „cipóknak” (5. ábra), magát a kőzetet pedig ez alapján „cipós homokkőnek” is szokás nevezni. Képződésének alapfeltétele, hogy legyen egy olyan, leggyakrabban szerves eredetű törmelékdarab (csigaház-, kagylóhéjtöredék), amely a kiválási mag központját képezi. A mag körül vándorló oldatban levő ásványi anyagok folyamatos hozzánövekedéssel válnak ki, jellegzetes, általában koncentrikus vagy sugaras szerkezetet létrehozva. Területünkön a kicsapódó anyag döntően a mész. A konkréció tömörebb a befogadó kőzetnél, ezért a lepusztulásnak is jobban ellenáll. Ezek alsó felületét a homokkő rétegfelszínének egyenletessége adja, így azok is sík felületűek. A felépítmény lekerekítettségét, gömbölyüségét a víz alatti áramlások irányítják. A bizarr alakú konkréciók valószínűleg több képződő gumó összenövése által jönnek létre.

A süllyedő tengerfenéken felhalmozódó homokanyagon a süllyedés és a behordódás ütemének megfelelően új és új rétegfelszínek alakultak ki. Ennek következtében a konkréciók képződése is újabb és újabb szinteken történt. Így a homokkő falakban feltáruló egyedi konkréciók vagy hosszabb, összefüggő padok, lemezek többszintes, emeletes elrendeződést mutatnak, mint az pl. jól látható a Lapác-kő homokkőfalán Nemti település határában (6. ábra). A kopár lejtőből kiemelkedő sziklabástya karcsúságát erősen limonitosodott keskeny védőkalapjának (ami nem más, mint a tetőt alkotó ellenállóbb konkréciós szint) köszönheti. A bástya alapja szélesen támaszkodik a mögöttes lejtőhöz.

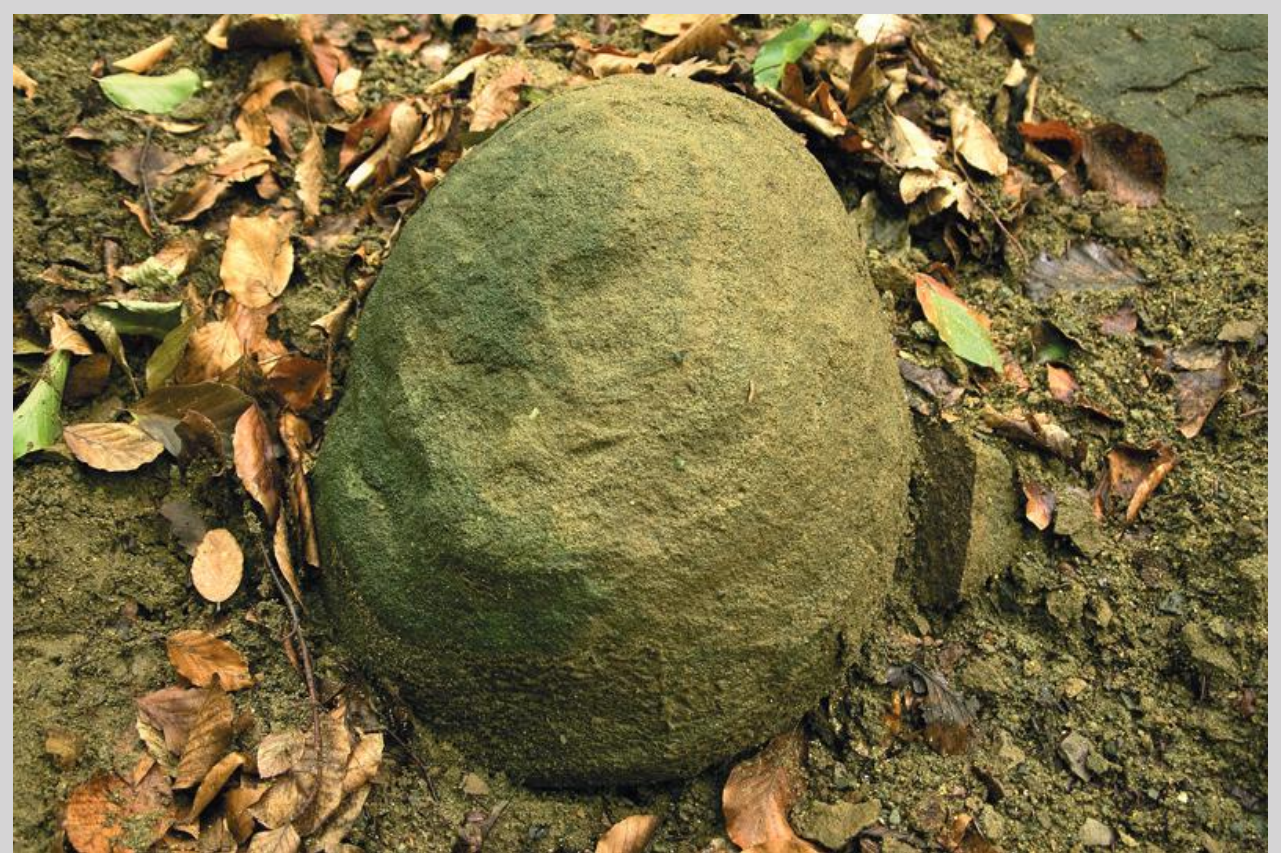




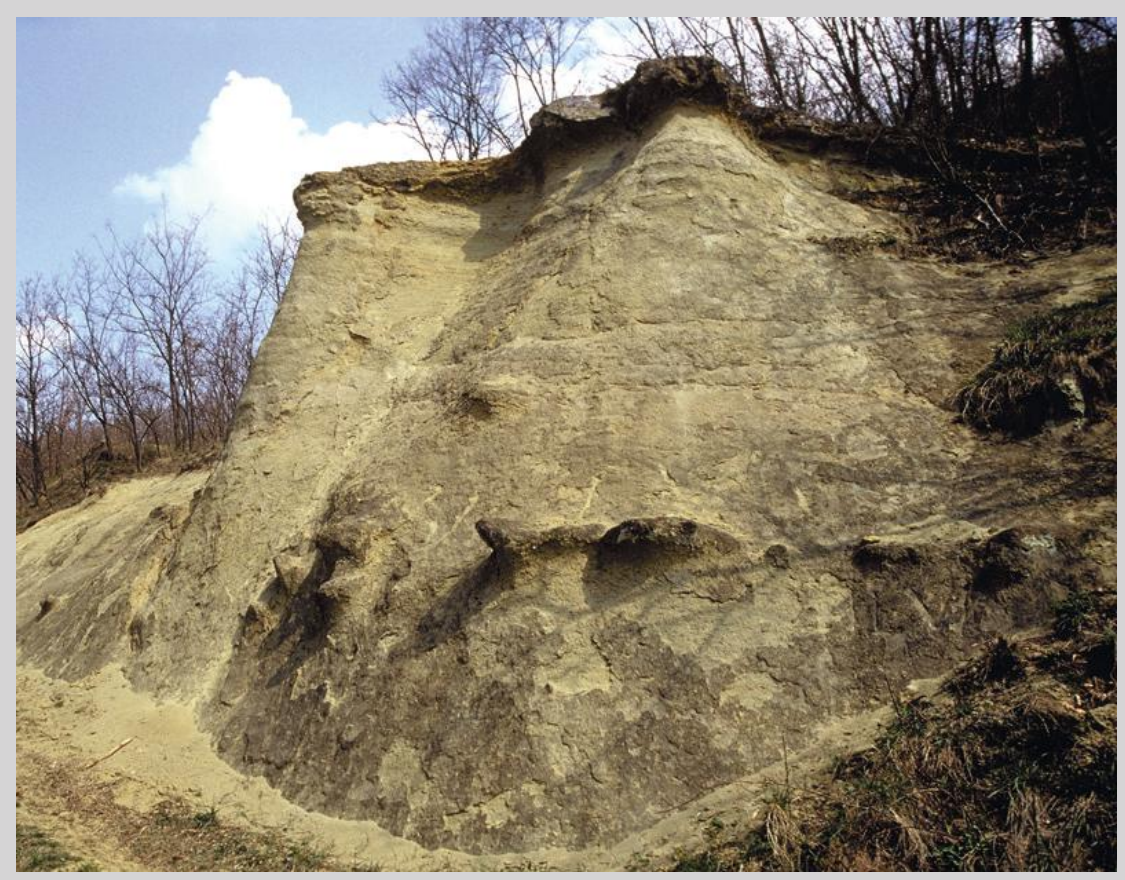

6. ábra. A Lapác-kö homokkőfala Nemti település határában konkréciós szintekkel (fotó: Horváth G.)

\section{A DOMBSÁG DÉLI PEREMÉNEK HOMOKKŐ FORMAKINCSE}

A terület tektonizáltsága és az erózió meredek, nagy lejtőszögü domboldalakat alakított ki, fóleg délies irányban. A vetődések által elnyírt kőzettömegek felülete kiváló felszínt biztosított a homokkőben rejtőző keményebb, kötöttebb, cementált rétegek, lemezek, padok, gumók kibontódásának, iskolapéldáját adva a válogató eróziónak. Különösen a víz és a fagyváltozékonyság okozta lepusztulás jelentős, a nyíltabb helyeken a szélerózió hatása is érvényesül. A vadcsapásokon a taposási erózió árkos kimélyülési folyamatok okozója, megindítója. A településekhez közeli homokkő felszínek az ember pusztító tevékenységét (csúszkálás, mászás, vésés) szenvedik el. A homokkövön képződött növény- és talajtakaró egyébként is vékony és sérülékeny, ezért megbontódása esetén nagyobb felületről lepusztulhat, kopár felszíneket, ún. sziklakopárosokat hátrahagyva. A homokkő csupasz, növényzettelen felületén elsősorban geokémiai okokból egy kemény kéreg alakul ki, amely azonban idővel szétesik, összetöredezik és főleg a lejtőleöblítés hatására lepusztul, a felszíni kéreg lényegében lehámlik, ezért ezt a jelenséget nevezhetjük hámlásos lekérgezödésnek (7. ábra). Ebben a zuzmók is gyakran szerepet játszanak, fonadékukkal átjárják és 


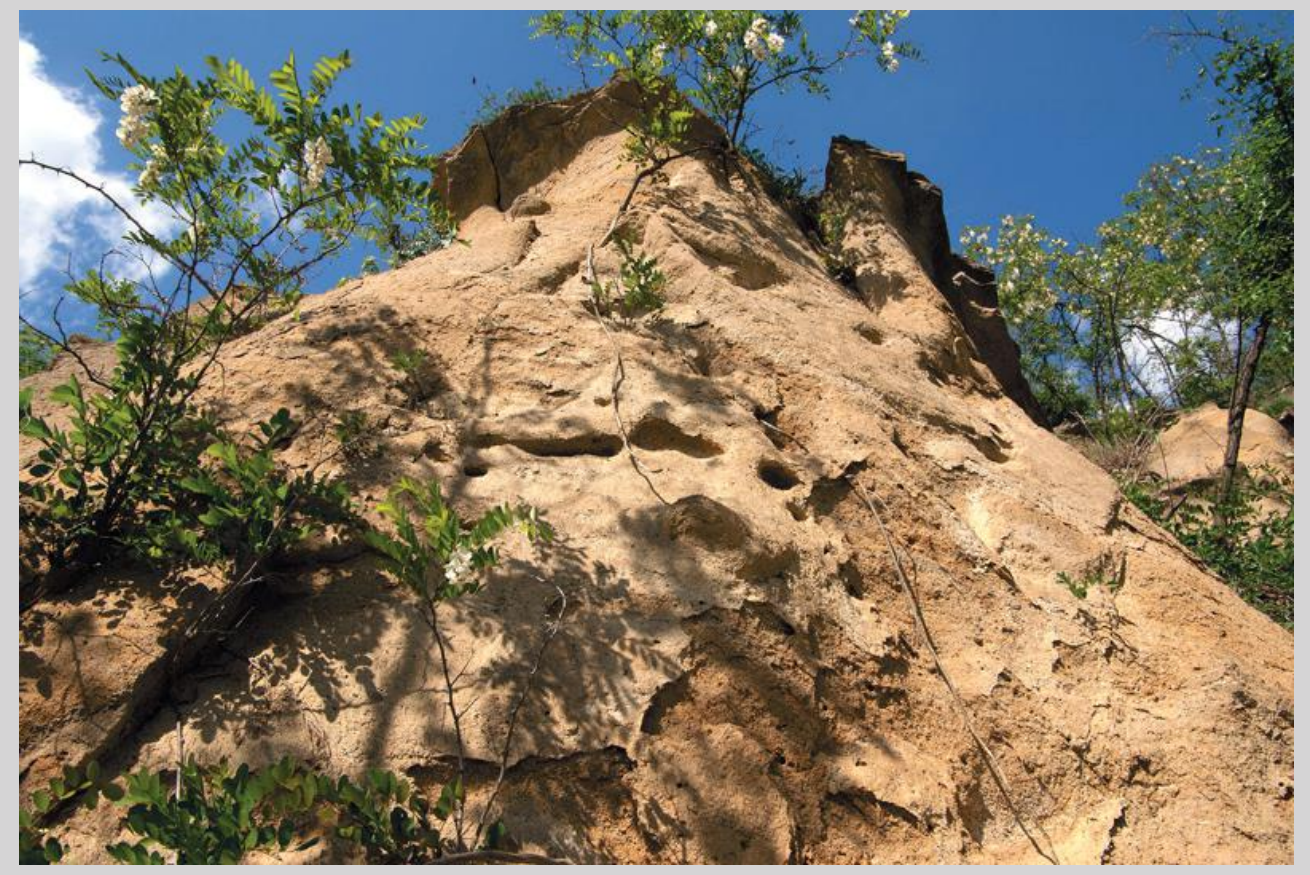

7. ábra. A Nemti környéki kopár sziklafalon jól látszik a hámlásos lekérgezödés (fotó: Karancsi Z.)

fel is lazítják a homokkő vékony felszíni rétegét, továbbá szerves vegyületeket is termelnek, amelyek hatására nő a mállás intenzitása (Pintér Z. 2003, HoRváTH G. 2007).

A homokkő formáinak fejlődését végigkövethetjük a lejtőkből éppen előbukkanó rétegfejektől, bordáktól kiindulva a lejtő fokozatos hátrálása miatt egyre jobban kiugró sziklapárkányokon, „cipókon”, korongokon át a sziklabástyák, gombasziklák kialakulásáig. Különösen a terület két része gazdag ezekben a formákban. Az egyik a Nemti települést körbevevő, kutatócsoportunk által Nemti-rögvidéknek elnevezett tájrészlet falu feletti sávja (2. ábra), a másik a Zagyva-Kazár-patak szegletében a 331 m-es magasságú Lószérü nevü csúcsot övezö rögcsoport.

A leglátványosabbak azok a sziklafalak, amelyek meredekségüknél fogva megőrizték az elsődleges tektonikai hatások (elnyíródás, vetődés, kibillenés) következményeit. A nagy lejtőszögü, sokszor közel függőleges falak maguk a vetősíkok, amelyek mentén az elmozdulás megtörtént, a falak hátráló pusztulása pedig lehetővé tette a konkréciók kipreparálódását, miáltal azok ma kiemelkednek a fal síkjából. A Nemti határában 354 m-ig emelkedő Első-Magos nevű rög nyugati gerincnyúlványának délnyugati fala tárja fel az északkeleties kibillenésű meszes homokkő padokon kialakult keskeny sziklapárkányokat (8. ábra). 


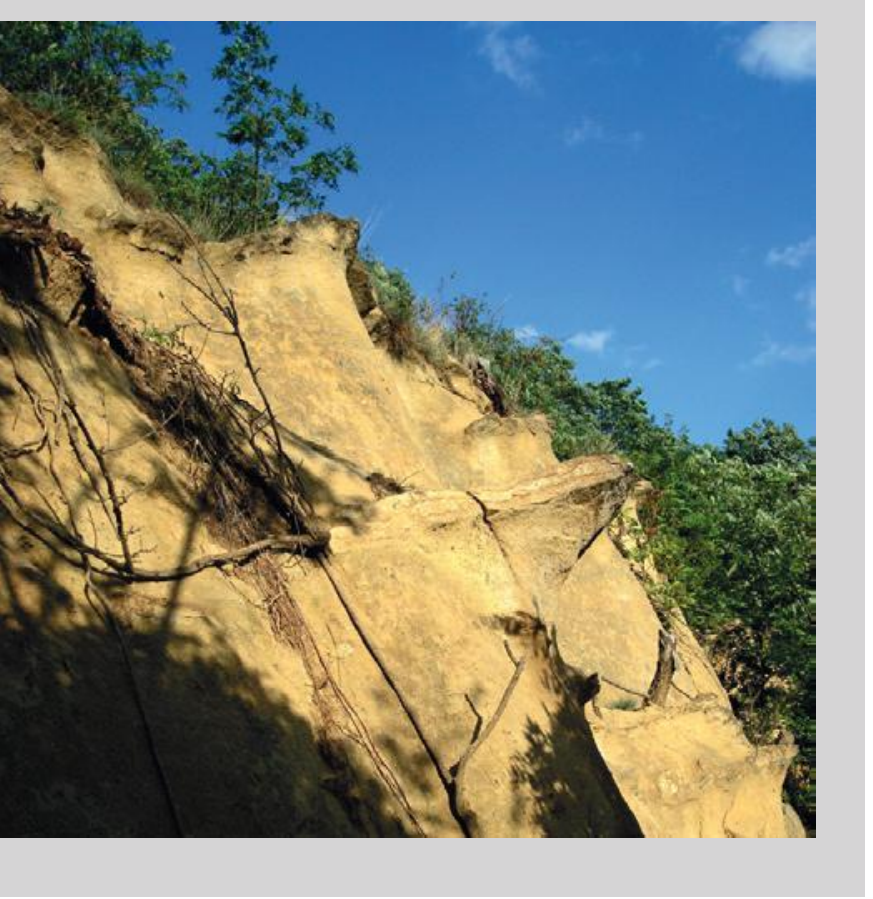

8. ábra. Lépcsözetes vetödések Nemti határában az Elsö-Magos rög oldalában (fotó: Karancsi Z.)

A lejtők felszínéből kibontakozó tömött meszes padok, konkréciók, „cipók” (9. ábra) alkotják a kialakuló nagyobb formák első fokozatát. Erősebb összecementáltságuknak köszönhető ellenállóbb voltuk folytán afféle kalapként védőtetőt képezhetnek az alattuk levő lazább, könnyebben pusztuló homokkövek számára. A homokkő anyagának felhalmozódása és kőzetté válása folyamán szingenetikusan képződő konkréciók alakja jellegzetesen lekerekített, legömbölyített. Ez látható a kőzetfalakból kibukkanó darabok sokaságán. A gömbölyded formák mellett azonban sok az éles szegélyü, tört felületű darab is. Ennek oka, hogy az ellenálló védőkalap alól a szél, a ferdén kibillent konkréciókról pedig az alácsorgó víz egyre több laza homokot szállít el, így a fedő homokkő egyre nagyobb darabja válik szabaddá, alátámasztás

9. ábra. A gombaszikla-képződés első fokozatát jelenítik meg a kipreparálódó konkréciós szintek (fotó: Karancsi Z.)

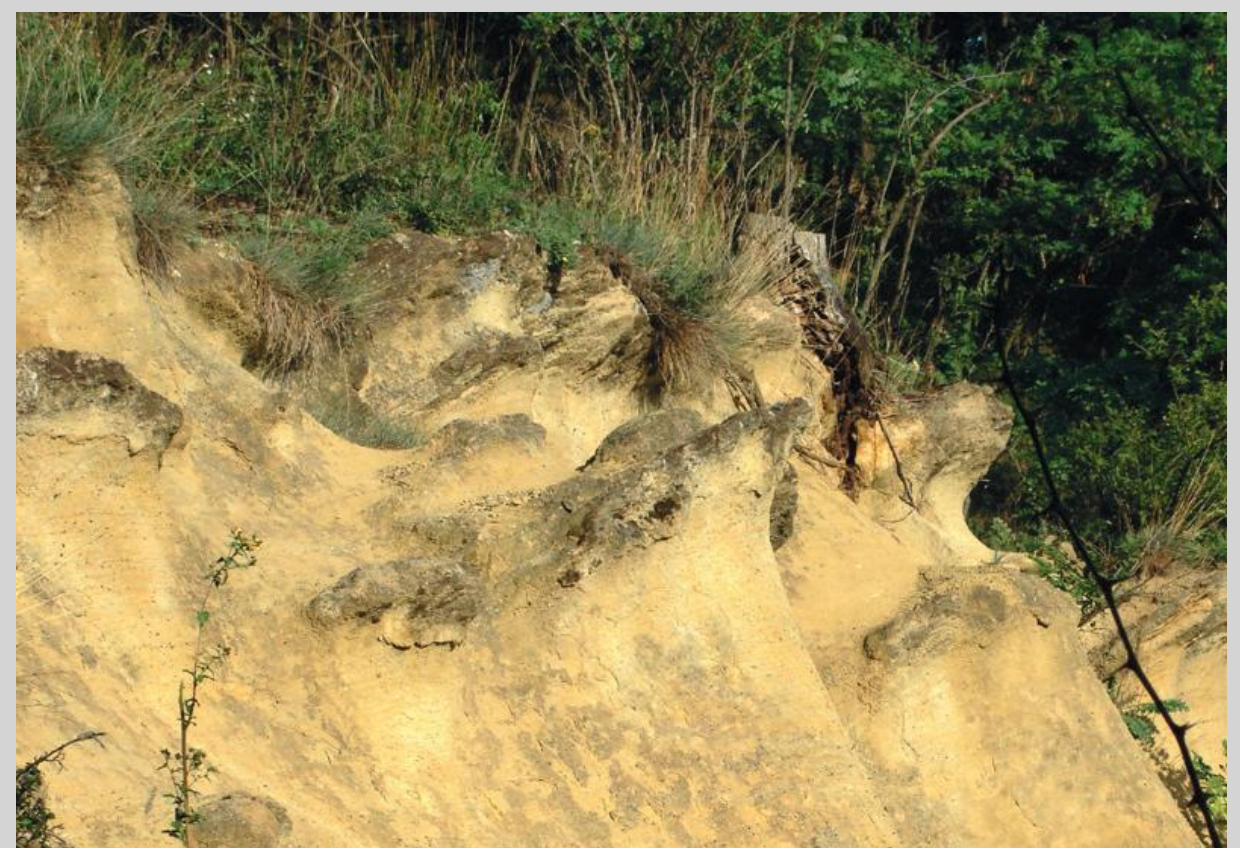


nélkülivé. Egy idő után a kemény homokkőből önsúlyánál fogva letörik, lehasad egy rész, és legurul a lejtőn.

A lepusztulás elörehaladtával a tömör homokkőkalap védelmében a kőzetfalból egyre jobban kidomborodó, oszlopszerü forma bontakozik ki. Ezeket a többnyire kúp vagy gúla alakú képződményeket nevezhetjük bástyáknak is. A bástyák kezdetben még széles nyakkal támaszkodnak a környező falhoz, de idővel az erózió a kalappal védett bástyát elkülöníti faltól, és az fokozatosan gombasziklává alakul. Ennek a folyamatnak az utolsó előtti fokozatát jeleníti meg a Hársas 292 m magas tetőszintje alatti lejtőből kiemelkedő Emberfej- vagy Törökfej-szikla (10. ábra), amelynek védőkalapját csupán egy elkeskenyedett nyak köti össze hátterével. A kúp alakú bástyát a nyak alatti eróziós vályú kezdi leválasztani. Fontos megjegyezni, hogy az ilyen formák nem a tetőn, hanem a hegyoldalban alakulnak ki.

A Nemti környéki homokkővidéken a gombasziklák „királynője” a Leány-kő (11. ábra), amelynek esetében a szikla már teljesen elkülönült a hátterét képező kőzetfalból. Ha a fejét nem is, a kalapját már elveszítette, így lassú lealacsonyodása folyik. A kőszál lábánál lejtőirányban látható „hiány” egy korábbi leválás eredménye, míg felette jól érzékelhető egy újabb várható leválás repedése. A lejtő irányából 8-10 m magas oszlop érdekessége még az árnyékmállás kifejlett fülkéje. Ennek kialakulása arra vezethető vissza, hogy a kőzettest kisebb üregeiben a kicsapódó pára az üreg falán válik ki, ahonnan cseppenként lehullva mindig magával ragad néhány szemcsét, és ez a folyamat folytonosan ismétlődve egyre változatosabb és nagyobb üregeket képes létrehozni. Mivel árnyékos helyen lévő üregekben kisebb mértékü a párolgás, a nedvesség ott jobban megőrződik, innen ered a jelenség neve.

Természetesen idővel maguk a gombasziklák is pusztulásnak indulnak, erre a folyamatra is akad nagyon tanulságos példa, a Nemti határában fekvő, Lapácnak nevezett sziklafalas tájrész lejtőjén levő Sárkányszikla. A háromkúpú képződmény

10. ábra. Az Emberfej-szikla (fotó: Pintér Z.)

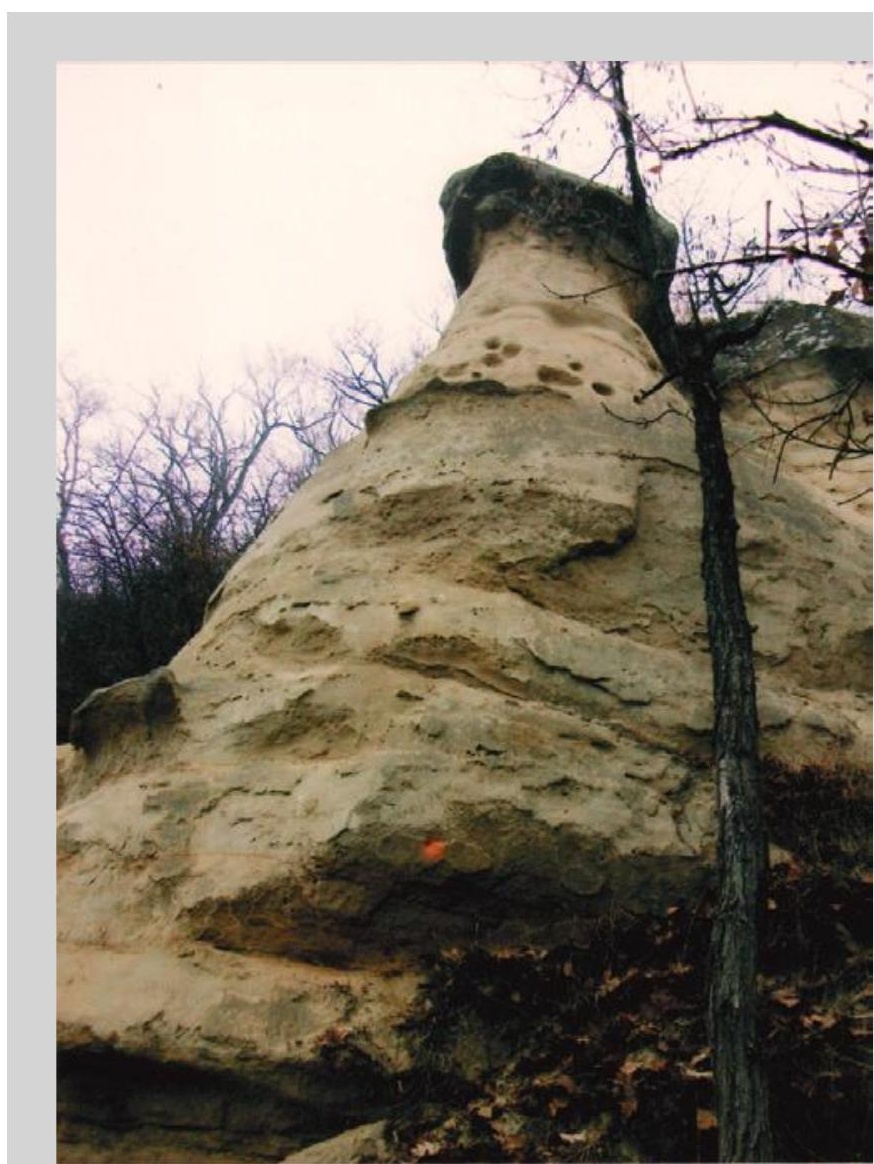




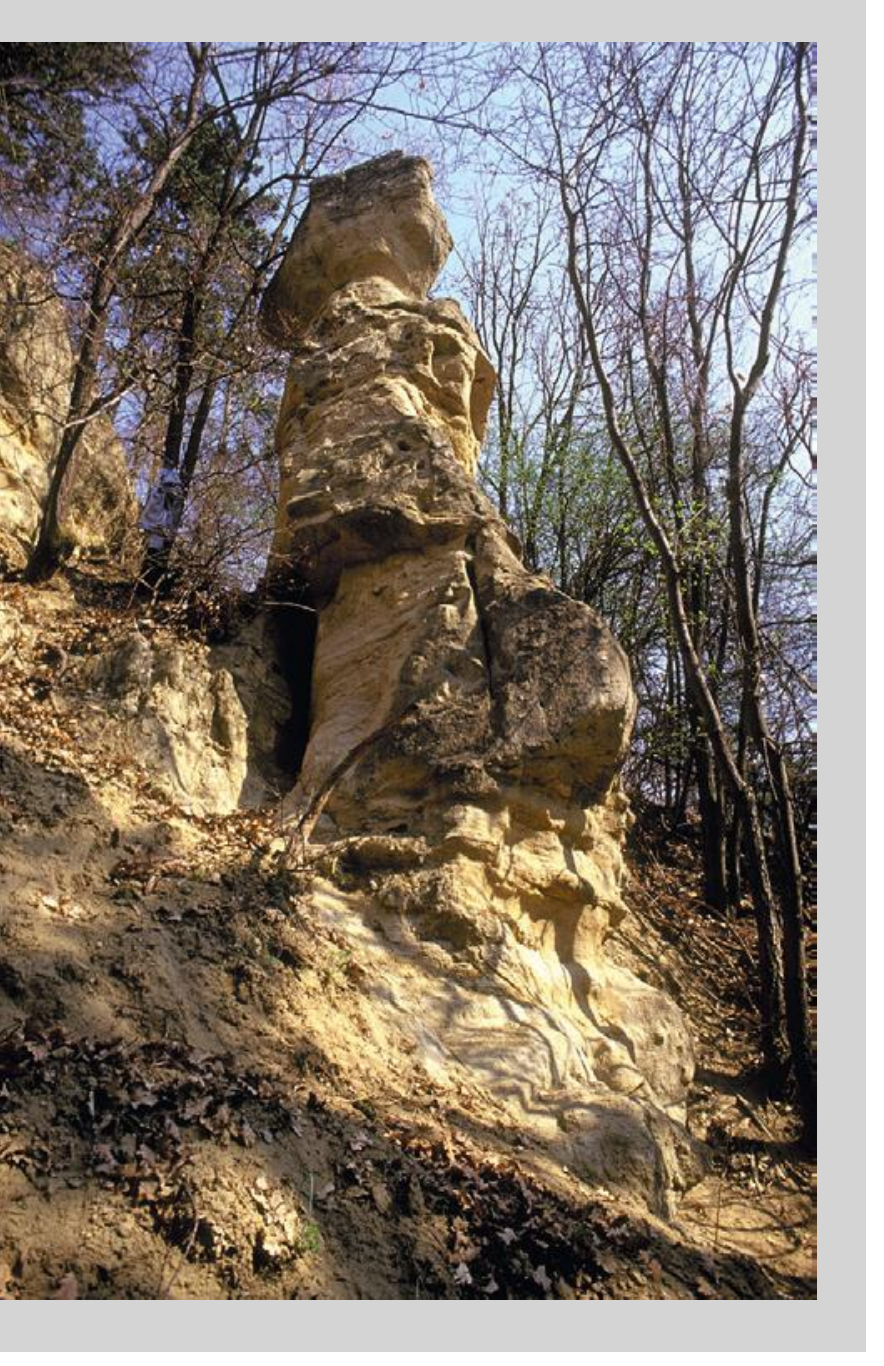

11. ábra. A Leány-kő (fotó: Karancsi Z.) mindegyik kúpja a fejlődés különböző szakaszát alkotja, jellemzi. A 12. ábrán jobbra látható középső, legmagasabb kúpot még védi a kalap, a nyugati (bal oldali) alacsonyabbról azonban már leesett a védőtető, a lepusztult kalap a képződmény közelében hever. A legalacsonyabb kúp vesztette el legkorábban a fedőjét, így lealacsonyodása a legelörehaladottabb. A szikla lejtöirányú oldalán látható az a már erősen kipreparált konkréciófüzér, amely a lepusztulás során majd a következő kúpképződés tetőszintje lesz. A képződményt az antropogén hatások is pusztítják, sajnos a falu közelsége miatt fokozottan veszélyeztetett, hiszen pl. a gyerekek csúszdának használják.

\section{ÖSSZEFOGLALÁS}

A Medves-vidék déli pereme homokkőképződményeinek bemutatásával egyrészt igyekeztem rámutatni arra, milyen kincsek rejtőzhetnek egy alig ismert tájrészleten, másrészt szerettem volna felhívni a figyelmet a terepi bemutatás lehetőségeire. A földrajzoktatás hatékonysága szempontjából fontos lehet, hogy egy természetföldrajzi jelenség kialakulási folyamatának különböző állomásait füzhetjük fel egy túra során. Természetesen a terepi bemutatást nehezíti a terület feltáratlansága, és persze a fentebb áttekintően tárgyalt képződmények sem fejlődésük genetikai sorrendjében helyezkednek el, így a tanártól komoly előkészületeket kívánhat a túra előkészítése, ezt azonban ellensúlyozza, hogy egy ilyen tanulmányi kirándulás a diákok szemét felnyithatja és ráirányíthatja a természet rejtett szépségeire, valamint arra, hogy az élettelen természet is állandóan változik, a formák fejlődnek, átalakulnak. A bemutatás a természetvédelmi nevelést is erősíti, egyúttal rámutathatunk 


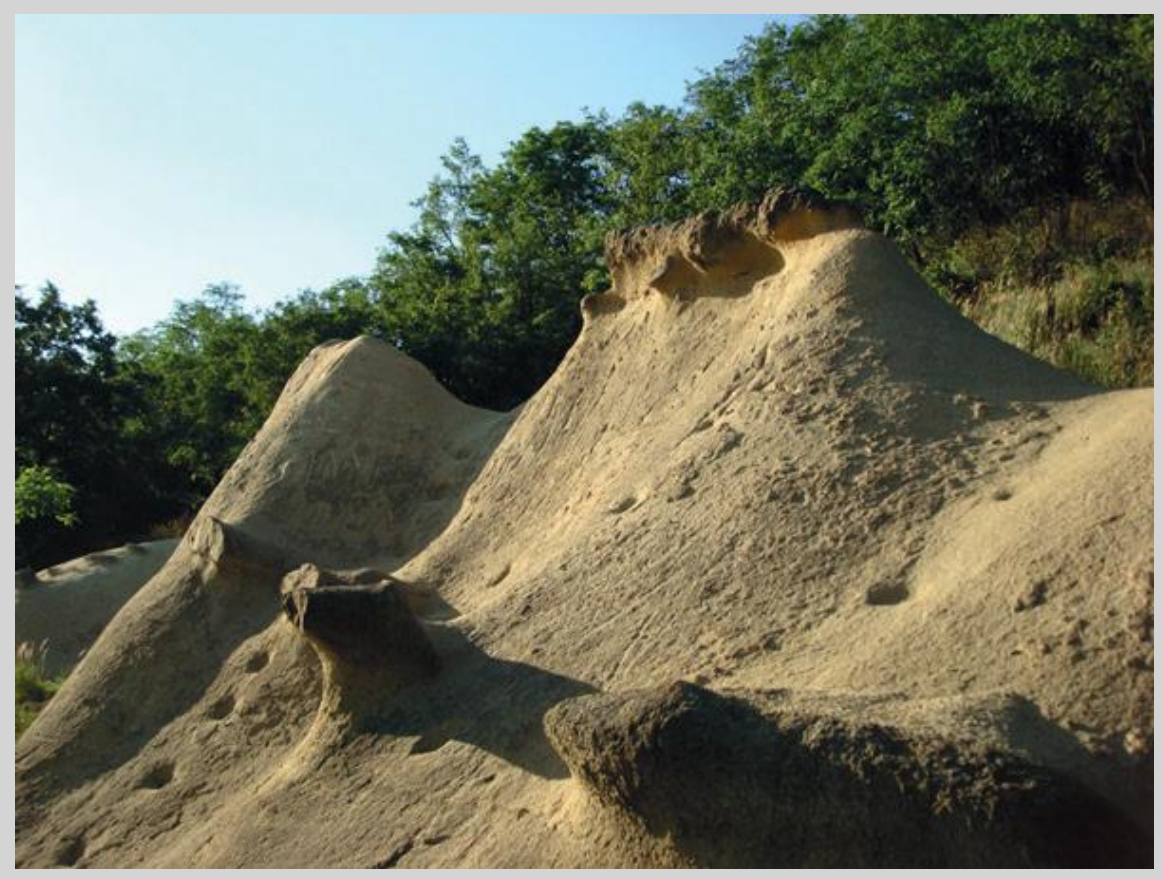

12. ábra. A Sárkány-szikla Nemti határában (fotó: Horváth G.)

arra is, hogy a rejtettségnek van egy pozitív oldala is, mégpedig az, hogy e képződmények java részét mindmáig alapvetőenmegkímélte az emberi rongálás.

\section{IRODALOM}

BÁLdi TAMÁs (1983): Magyarországi oligocén és alsómiocén formációk. - Akadémiai Kiadó, Budapest. $292 \mathrm{p}$.

BÁLdi TAMÁs (2003): Egy geológus barangolásai Magyarországon. - Vince Kiadó, Budapest. 198 p.

Balogh Kálmán - Hajdúné Molnár Katalin (1991): Homokok és homokkövek. - In: Balogh Kálmán (szerk.): Szedimentológia II. Akadémiai Kiadó, Budapest. pp. 102-157.

GaÁl Lajos - Horváth Gergely (2007): Domborzat, felszínformák, felszínfejlődés, felszínalaktani értékek. - In: Kiss Gábor - Baráz Csaba - Gaálová, Katerina - Judik Béla (szerk.): A Karancs-Medves és a Cseres-hegység Tájvédelmi Körzet. Nógrád és Gömör határán. Bükki Nemzeti Park Igazgatóság, Eger. pp. 57-78.

Gyalog LÁszló (szerk., 1996): A földtani térképek jelkulcsa és a rétegtani egységek rövid leírása. - Magyar Állami Földtani Intézet, Budapest. 171 p.

HÁmoR GÉZA (1985): A Nógrád-cserháti kutatási terület földtani viszonyai. - Geologica Hungarica. Series 
Geologica 22. Magyar Állami Földtani Intézet, Budapest. 307 p.

Horváth Gergely (1997): A Cserhát, a Medvesvidék és a Gömör-Hevesi-dombság. - In: Karátson Dávid (szerk.): Magyarország földje. Pannon Enciklopédia. Kertek 2000 Kiadó, Budapest. pp. 333-336.

Horváth Gergely (1998): A Medves-vidék természeti képe. - In: Frisnyák Sándor (szerk.): A Felvidék történeti földrajza. MTA Szabolcs-Szatmár-Bereg megyei Tudományos Testülete - Bessenyei György Tanárképző Főiskola Földrajz Tanszéke, Nyíregyháza. pp. 63-72.

Horváth Gergely (2007): Közetminőséghez kötött formák az Északi-középhegység egyes homokköves kistájain. - In: Frisnyák Sándor - Gál András (szerk.): Peja Győző emlékkönyv. Nyíregyházi Főiskola Turizmus és Földrajztudományi Intézete - Szerencsi Bocskai István Gimnázium, NyíregyházaSzerencs. pp. 57-78.

Horváth Gergely - Utasi Zoltán - Hegedüs András - Pintér Zoltán (2015): The Vajdavár Hills: sandstone cliffs, hoodoos and gorges. - In: Lóczy Dénes (szerk.): Landscapes and landforms of Hungary. Springer, Heidelberg. pp. 157-165. https://doi.org/10.1007/978-3-319-08997-3_19

Kocsis KÁroly (főszerk. 2018): Magyarország Nemzeti Atlasza. Természeti környezet. - Magyar Tudományos Akadémia Csillagászati és Földtudományi Kutatóközpont Földrajztudományi Intézet, Budapest. $187 \mathrm{p}$.

Pintér Zoltán (2001): Felszínalaktani megfigyelések a Medves-vidéken. - Magyar Földrajzi Konferencia, Szeged. CD. 7 p.

PInTÉR Zoltán (2003): A Nemti-rögvidék felszínalaktana. - In: Horváth Gergely (szerk.): A földrajz szolgálatában. Eötvös Loránd Tudományegyetem Tanárképző Főiskolai Kar Földrajz Tanszék. BudapestÉrd. pp. 103-116.

Prakfalvi Péter - GaÁl Lajos - Horváth Gergely (2007): Földtani felépítés, szerkezeti viszonyok, földtani értékek. - In: Kiss Gábor - Baráz Csaba - Gaálová, Katarína - Judik Béla (szerk.): A KarancsMedves és a Cseres-hegység Tájvédelmi Körzet. Nógrád és Gömör határán. Bükki Nemzeti Park Igazgatóság, Eger. pp. 13-42.

Sztanó Orsolya (1994): The tide-influenced Petervására sandstone, Early Miocene, Northern Hungary: sedimentology, paleogeography and basin development. - Geologica Ultraiectina 120. Utrecht. 155 p,

Veres Zsolt - Varga Andrea (2020): Karbonátos konkréciók az alsó-miocén Pétervásárai Homokkő Formációban (Pétervásárai-dombság, Leleszi-völgy): genetikai megfontolások morfológiai és petrográfiai vizsgálatok eredményei alapján. - Földtani Közlöny 150. 3. pp. 429-448. https://doi. org/10.23928/foldt.kozl.2020.150.3.429 